\title{
Digital Archive
}

National Cancer Institute

\section{Source}

National Cancer Institute. Digital Archive. NCI Thesaurus. Code C114463.

A storage location for historical digital data. 